\title{
13. NEOGENE BENTHONIC FORAMINIFERA FROM SITE 369, LEG 41, DEEP SEA DRILLING PROJECT
}

\author{
Gerhard F. Lutze, Geological Institute of Kiel University, Kiel, Germany
}

\begin{abstract}
A statistical study of late Neogene benthonic Foraminifera reveals relatively low faunal fluctuation, as compared with the glacial Pleistocene. A Uvigerina maximum is correlated with a cooling trend indicated by the planktonic fauna and is believed to reflect changes in bottom water conditions. In addition, the ranges of main benthonic species were established down to the Oligocene boundary. Displaced shelf faunas in the upper early Miocene indicate downslope sediment transport. Selective dissolution, the occurrence of Uvigerina, and upslope migration of Melonis pompilioides characterize the cooling period of the lower early Miocene.
\end{abstract}

\section{INTRODUCTION}

Benthonic Foraminifera were studied in 85 samples from the Neogene part of the section at Site 369. The site was drilled in 1760 meters water depth off Cape Bojador, West Africa. The location is shown in Figure 1. The section includes a thin Pleistocene interval, a 12 meter-thick incomplete Pliocene section and approximately 151 meters of Miocene sediments (the Pliocene-Miocene boundary used is that of Krasheninnikov and Pflaumann, this volume).

The study was carried out in order to: (1) discover whether faunal fluctuations observed in "Meteor" cores of the same area are restricted to the glacial Pleistocene, and (2) investigate Neogene deep-water Foraminifera and their depth distribution.

\section{FLUCTUATION, TRENDS, AND CLIMATIC CHANGES}

A statistical analysis was carried out to determine species composition for the younger part of the Neogene section. A total of 45 samples was analyzed on size fractions larger than $250 \mu \mathrm{m}$. The main features are a faunal break between Pleistocene and Pliocene, relatively low fluctuations, and a correlation between Uvigerina and cool water planktonics (Figure 2).

The sharp break at the top of the Pliocene corresponds to a hiatus (Pflaumann and Krasheninnikov, this volume).

The proportions of the dominant species remain relatively constant, especially during the late Miocene and Pliocene, although often less than 100 specimens per sample were available for counting. This is in contrast to distinctive fluctuations observed in Pleistocene "Meteor" cores from the same area (Figure 3 ). If these changes only reflect minor shifts of depth habitat or statistical artifacts only randomly correlated with planktonic climatic trends, then they should not be restricted to the Pleistocene.
A faunal change at the base of the Globorotalia margaritae Zone is caused by increased proportions of Uvigerina auberiana and $U$. hispida, which are dominant in most of the samples up to the Pleistocene. Figure 4 shows this trend to be correlated with a distinct shift towards "cooler" planktonic faunas (Pflaumann and Krasheninnikov, this volume). A causal relationship between changes in bottom-water configuration and Uvigerina frequencies is tentatively suggested because glacial periods in Pleistocene sections are also characterized by Uvigerina peaks (Figure 3 ). This suggestion is strengthened by the first appearance of Uvigerina which occurs at the first period of major cooling in the early Miocene (Figure 7). This result is

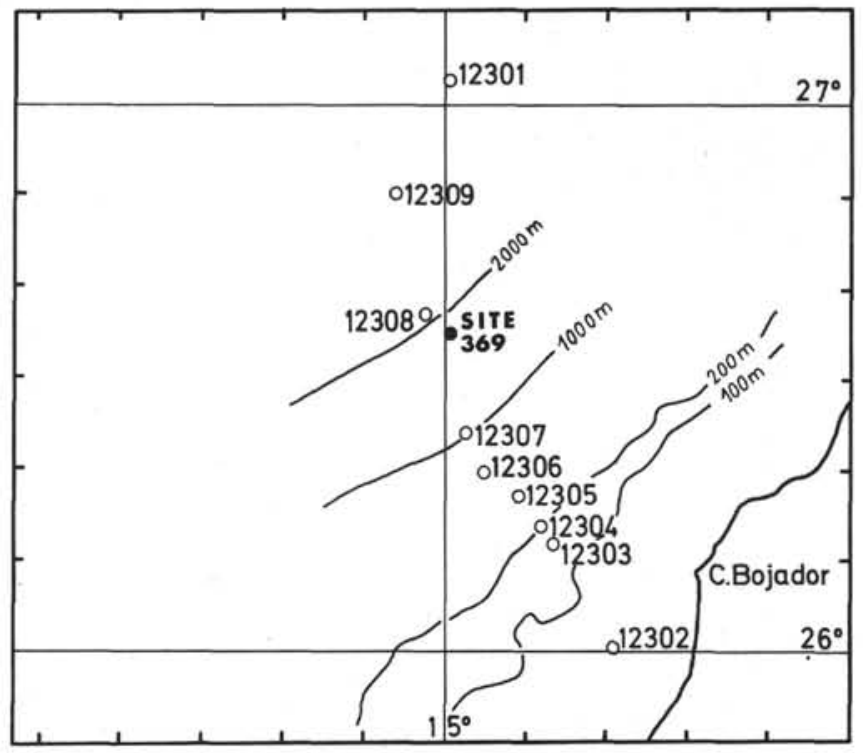

Figure 1. Map of drilling site. Location of surface samples used for depth distribution information given on Figure 6. 

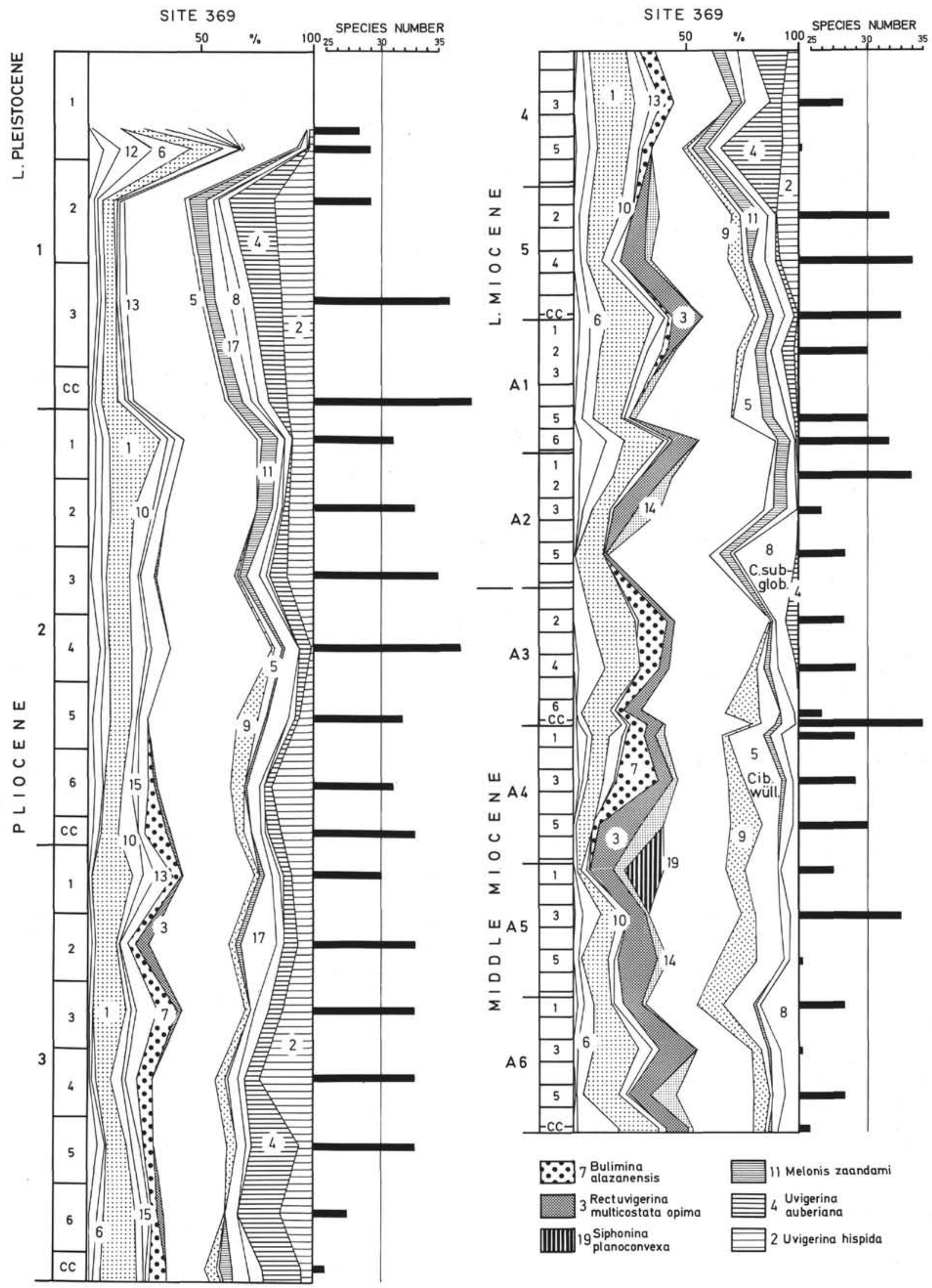

Figure 2. Cumulative percentage diagram showing fluctuation of dominant benthonic species during the late Neogene. Fraction $>250 \mu \mathrm{m}$ ? species are marked with numbers, given in Table 1 . Note the relative low fluctuation of Uvigerina species (horizontal hatching, no. 2 and 4) and their first appearance in the cooler late Miocene in Core 369A, Section 1. The typical Miocene Rectuvigerina m. opima (no. 7) continues up to the Pliocene. Species diversity (black horizontal bars: species numbers referred to 100 counted specimens) is higher in the upper part of the section and lower in the middle Miocene. 


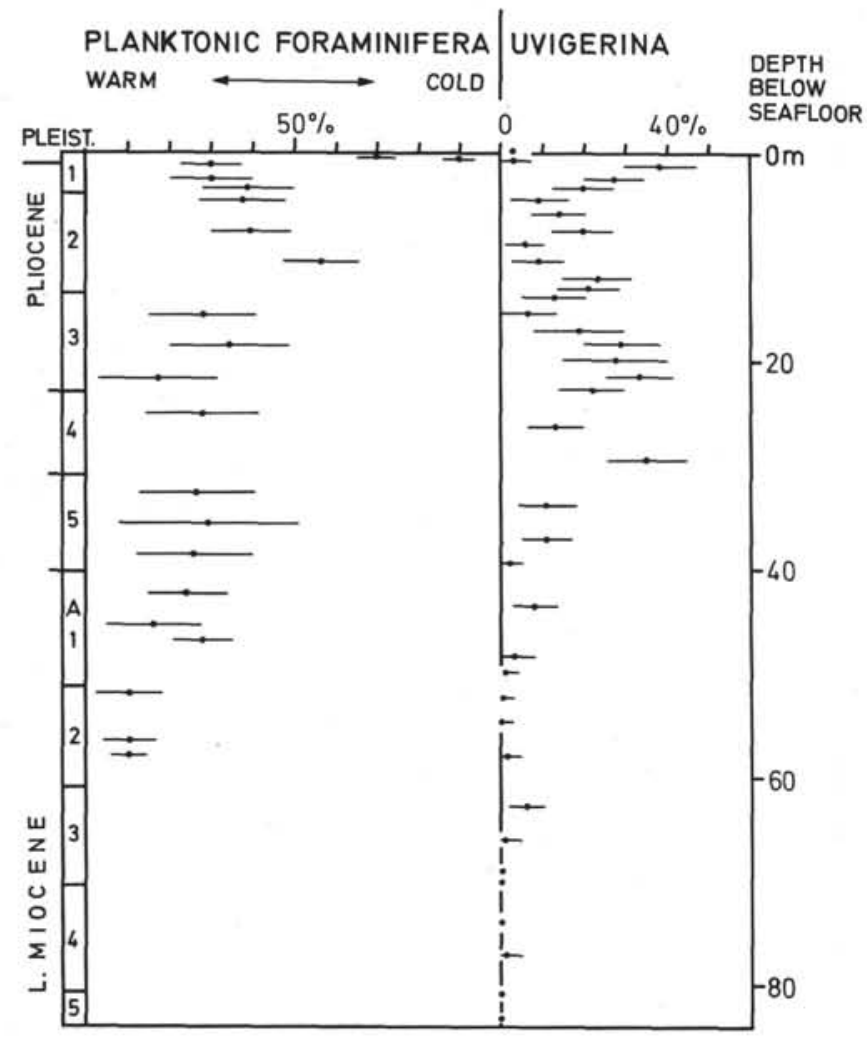

Figure 3. Pliocene increase of cool-water planktonic Foraminifera, compared with percentages of both, Uvigerina auberiana and U. hispida. The "cooling trend" is matched by increased Uvigerina-proportions, but no peak-for-peak correlation is possible. Planktonic Foraminifera data are from Pflaumann and Krasheninnikov (this volume). Horizontal bars have confidence limits at $5 \%$ level.

similar to that of Schnitker (1974) who uses benthonic foraminiferal populations to reconstruct circulation changes of the North Atlantic.

Species diversity is indicated on Figure 2 by horizontal bars and the diversity field is given in Figure 5. Diversity is indicated as "species number" which is related to a theoretical count of 100 specimens. The relatively low diversity in the middle Miocene (Figure 2) may be the result of selective dissolution of carbonate tests, as suggested by Douglas (1973). Diversity reaches the lowest point in the lower early Miocene where nearly all planktonic tests are destroyed by dissolution.

The most dominant species in the late Neogene section are Cibicidoides kullenbergi s.l., Uvigerina hispida, Rectuvigerina multicostata opima, and Uvigerina auberiana. They were reported among the first three ranked species more than 10 times (for complete list see Table 1). In general, the species composition of the Neogene benthonic population is similar to that described by Cushman (1929) from the oceanic Miocene of Venezuela and Trinidad. Most of the Neogene species recorded by Douglas (1973) and Ingle (1973) from lower middle bathyal depths of the northern Pacific are also present at Site 369. This wide interocean distribution of bathyal Neogene foraminifera should stimulate future correlation studies with benthonic foraminifera.

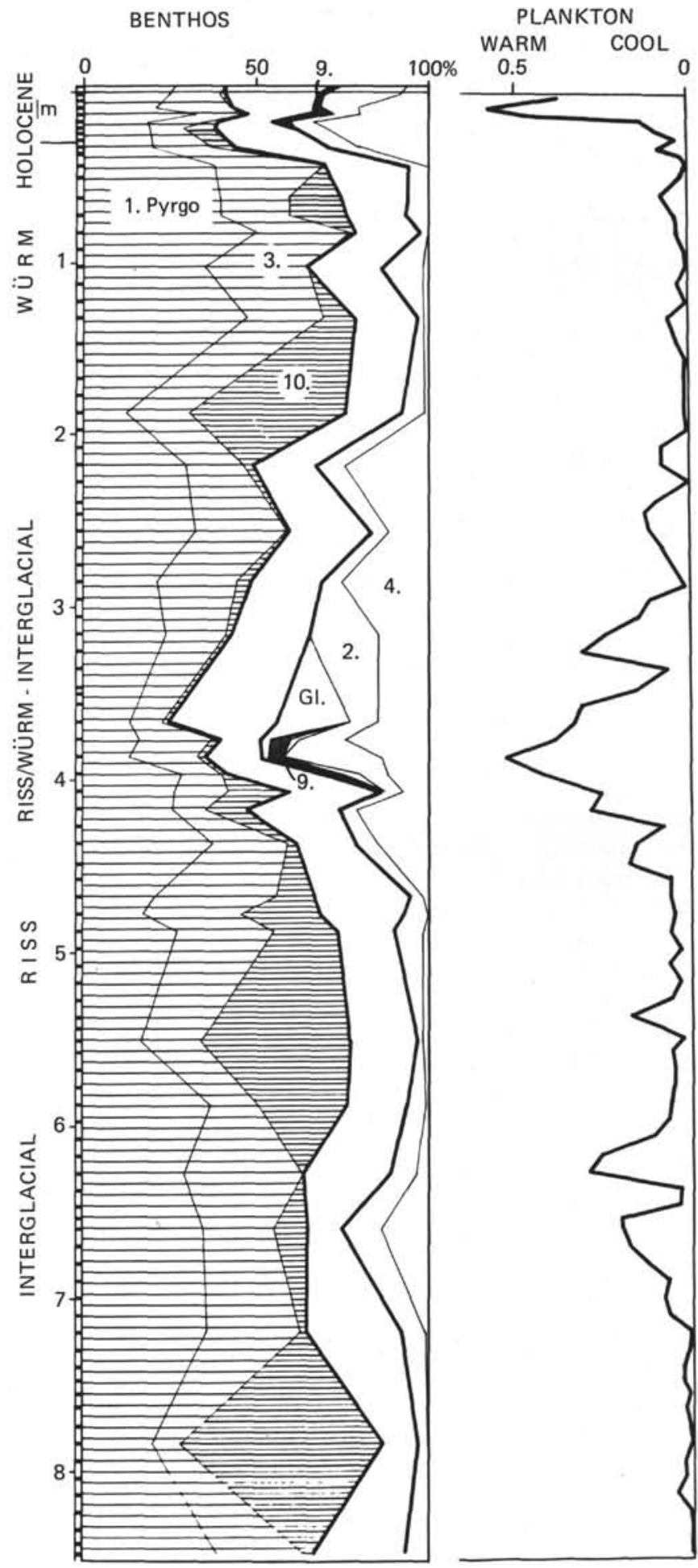

Figure 4. Meteor Core 1329-6, off Cape Timiris.-The late Pleistocene section of this core shows significant correlation between Uvigerina peregrina peaks (no. 10) and glacial periods indicated by planktonic Foraminifera. Fraction $>300 \mu \mathrm{m}$. "Paleotemperature index" values of planktonic Foraminifera are from Pflaumann (1975). They are ratios between extreme tropical species and both, tropical and polar species. The benthonic population shows an increase of Hoglundina elegans (no. 4) and Cibicidoides robertsonianus (no. 2) during warmer periods. 


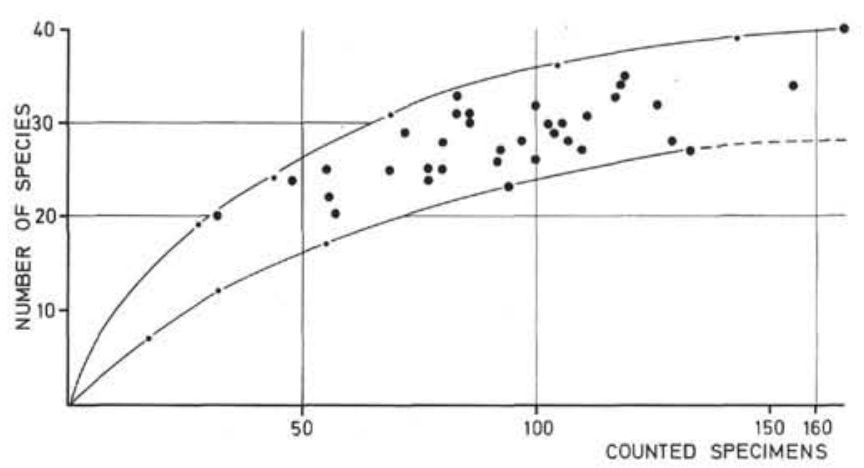

Figure 5. Diversity field of benthonic Foraminifera larger than $250 \mu \mathrm{m}$. The samples yielded between 24 and 34 species, referred to a number of 100 identified specimens.

\section{PALEOBATHYMETRY}

Benthonic foraminifera have been frequently used for paleodepth interpretation (Bandy and Chierici, 1966). It is obvious, however, that foraminiferal distribution reflects water-mass distribution rather than absolute depth. This was shown in the Baltic Sea where shallow shelf species submerge with inflowing high salinity water into the deep basins (Lutze, 1965). It was recently demonstrated by Schnitker (1974) for the bathyal West Atlantic and by Douglas (1975). It does not seem justified, therefore, to interpret minor bathyal faunal changes as a result of epirogenetic uplift and subsidence or sea-level changes. They indicate with greater certainty changes in bottom water properties caused by climatic events.

An example is the increased abundance of Melonis zaandami, Cassidulina subglobosa, and Uvigerina auberiana in the G. margaritae Zone. The modern depth distribution of these species at Site 369 (Figure 6) is shallower than the depth of the site. However, the extended depth range of $M$. zaandami farther south and north (see white bar, Figure 6) and the combined occurrence with typical lower middle bathyal species precludes depth changes as an interpretation. More likely, a cooling trend resulted to enable an extended depth range of these species. One possible explanation would be a higher supply of nutrients.

A different case is the restricted occurrence of Melonis pompilioides in the lower part of the early Miocene section. This species is believed to be indicative of lower bathyal depths (Bandy and Chierici, 1966). This species is absent in surface sediments at Site 369. The observed early Miocene upslope migration takes place at a time of cooling, ice cap formation, changed bottom water circulation, and local upwelling (Sarnthein, this volume). Living conditions for this particular species were provided in shallower water than usual. In other words, upslope as well as downslope shifts of depth habitat are possible and might be caused by the same general climatic trend.

\section{INDICATIONS OF DOWNSLOPE TRANSPORT}

The limited utility of benthonic foraminifera for paleobathymetrical conclusions, as discussed above, does not apply to the well-known differences between shelf and bathyal faunas. The following species are considered allochthonous components indicating downslope transport from source areas at the outer shelf and upper slope: Bolivina dilatata, Buliminella $\mathrm{cf}$. tenuata, Nonion asterizans, Hanzawaia producta, and Nonionella $\mathrm{sp}$.

These species occur with autochthonous bathyal species, but are restricted to the early Miocene and to the fractions $<250 \mu \mathrm{m}$. Higher abundances and more typical shelf species were observed in the upper part of the lower Miocene section in Samples 369A-9-2 and 369A-9, CC.

\section{DISSOLUTION OF CARBONATE TESTS}

The lower part of the early Miocene section is characterized by foraminiferal assemblages strongly affected by differential dissolution of carbonate tests (see Figure 7). Practically no planktonic shells were observed in the fraction $>250 \mu \mathrm{m}$. The benthonic assemblages are dominated by thick-walled species, especially Uvigerina gallowayi. It seems to be impossible to explain this phenomenon by general movements of the CCD because pelagic faunas of the same age are preserved in deeper water and the lysocline (CCD) is supposed to have been lowered during the first major cooling (Sarnthein, this volume). Only local fluctuations of the CCD, caused by high productivity due to upwelling, might be responsible for these dissolution effects in relatively shallow water.

\section{BIOSTRATIGRAPHY}

Our present knowledge on ranges and geographic distribution of Neogene deep water Foraminifera is insufficient for precise age determination. No zonal systems based on benthonic Foraminifera have been established. Figure 7 shows that most species have rather extended ranges. Comparable results are given for the Pacific by Douglas (1973), Ingle (1973), and Parker (1964).

Biostratigraphic “units," shown on Figure 7, must remain of descriptive and local value only. They are differentiated as follows:

Unit 1 is characterized by large Uvigerina gallowayi and $U$. auberiana, $U$. hispida, and Bolivina mantaensis. The lower bathyal Melonis pompilioides indicates cool deep-water conditions moved upslope. The faunal appearance is influenced by selective dissolution. The unit roughly corresponds to Neogene planktonic Zones $\mathrm{N} 4$ to N6 representing 21 to 18 m.y.B.P. (lower early Miocene).

Unit 2 contains Uvigerina gallowayi, but, in addition Cassidulina subglobosa and Rectuvigerina multicostata opima occur.

$U$. auberiana and $U$. hispida have disappeared. Increasing numbers of displaced shelf Foraminifera are observed within the finer fractions. Trifarina bradyi indicated transport from upper slope source areas.

Unit 3 (the base) is defined by the first occurrence of Sigmoilopsis schlumbergeri and Cibicidoides wïllerstorfi and the disappearance of $U$. gallowayi. Displaced shelf species, especially Bolivina dilatata, are abundant. Units 
TABLE 1

Species List and Taxonomical References

\begin{tabular}{|c|c|c|c|}
\hline & Rept. & $\%$ & Reference; Figure \\
\hline \multicolumn{4}{|l|}{ Dominant Species (See Figure 2) } \\
\hline $\begin{aligned} & 1 \text { Cibicidoides kullenbergi (Parker) s.1. } \\
& 2 \text { Uvigerina hispida Schwager } \\
& 3 \text { Rectuvigerina multicostata opima (Cushm.) } \\
& 4 \text { Uvigerina auberiana Orbigny } \\
& 5 \text { Cibicidoides wullerstorfi (Schwager) } \\
& 6 \text { Oridorsalis umbonatus (Reuss) } \\
& 7 \text { Bulimina alazanensis Cushman } \\
& 8 \text { Cassidulina subglobosa } \text { Brady } \\
& 9 \text { Sphaeroidina bulloides Orbigny } \\
& 10 \text { Sigmoilopsis schlumbergeri Silvestri } \\
& 11 \text { Melonis zaandami } \text { (Voorthuysen) } \\
& 12 \text { Bulimina striata mexicana Cushman } \\
& 13 \text { Pullenia bulloides (Orbigny) } \\
& 14 \text { Bulimina } \text { cf. jarvisi Cushman and Parker } \\
& 15 \text { Karreriella bradyi (Cushman) } \\
& 16 \text { Osangularia cultur (Parker and Jones) } \\
& 17 \text { Gyroidina orbicularis (Orbigny) } \\
& 18 \text { Cibicidoides robertsonianus (Bradyi) } \\
& 19 \text { Siphonina planoconvexa (Silvestri) }\end{aligned}$ & $\begin{array}{l}34 \\
17 \\
11 \\
10 \\
8(+3) \\
7 \\
6 \\
6 \\
5 \\
4 \\
4 \\
3 \\
3 \\
3 \\
2 \\
2 \\
1 \\
1 \\
1\end{array}$ & $\begin{array}{r}25 \\
13 \\
8 \\
7 \\
8 \\
5 \\
4 \\
4 \\
4 \\
3 \\
3 \\
2 \\
2 \\
2 \\
1 \\
1 \\
1 \\
1 \\
1\end{array}$ & $\begin{array}{l}\text { Parker, 1964; pl. 100/20, 24, } 25 \\
\text { Cushman, 1929; pl. 13/35 } \\
\text { Cushman, 1943; pl. 16/9,10 } \\
\text { Phleger et al., 1953; pl. 7/30-32 } \\
\text { Phleger et al., 1953; pl. 11/1, } 2 \\
\text { Parker, 1964; pl. } 91 / 4-6 \\
\text { Parker, 1964; pl. 98/19 } \\
\text { Parker, 1964; pl. 99/29 } \\
\text { Parker, 1964; pl. 98/18 } \\
\text { Phleger et al., 1953; pl. 5/17 } \\
\text { Loeblich and Tappan, 1964; pl. 627/2,3 } \\
\text { Phleger et al., 1953; pl. 6/27 } \\
\text { Parker, 1964; pl. 100/7 } \\
\text { Douglas, 1973; pl. 7/9-11 } \\
\text { Parker, 1964; pl. 97/8 } \\
\text { Phleger et al., 1953; pl. 9/11-16 } \\
\text { Loeblich and Tappan, 1964; pl. 749/5 } \\
\text { Phleger et al., 1953; pl. 11/15-17 } \\
\text { Verdenius, 1970; pl. 7/6 }\end{array}$ \\
\hline \multicolumn{4}{|l|}{ Additional Species (Ranges given in Figure 7) } \\
\hline $\begin{array}{l}20 \text { Hoeglundina elegans (Orbigny) } \\
21 \text { Laticarinina pauperata (Parker and Jones) } \\
22 \text { Cibicidoides cicatricosus (Schwager) } \\
23 \text { Gyroidina zeelandica Finlay } \\
24 \text { Anomalina globulosa Chapmann and Parr } \\
25 \text { Cibicidoides } 369-4-3 \\
26 \text { Pyrgo murrhina (Schwager) } \\
27 \text { Stilostomella lepidula (Schwager) } \\
28 \text { Vulvulina pennatula (Batsch) } \\
29 \text { Spiroloculina canaliculata Orbigny } \\
30 \text { Gyroidina lamarckiana (Orbigny) } \\
31 \text { Pleurostomella acuminata Cushman } \\
32 \text { Uvigerina gallowayi Cushman } \\
33 \text { Bolivina mantaensis Cushman } \\
34 \text { Bolivina antiqua Orbigny } \\
35 \text { Melonis pompilioides (Fichtel and Moll) } \\
36 \text { Ubigerina peregrina - group }\end{array}$ & & & 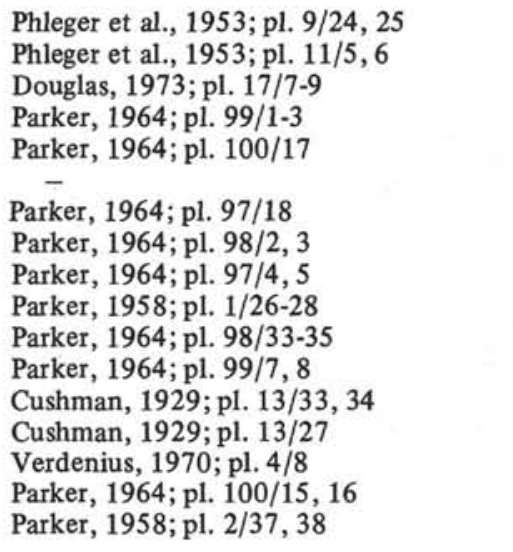 \\
\hline \multicolumn{4}{|l|}{ Displaced Slope (?) and Shelf Foraminifera } \\
\hline $\begin{array}{l}37 \text { Trifarina bradyi Cushman (slope?) } \\
38 \text { Bolivina dilatata } \text { Reuss } \\
39 \text { Buliminella } \text { cf. tenuata Cushman, } 1927 \\
40 \text { Nonion asterizans (Fichtel and Moll) } \\
41 \text { Hanzawaia producta (Terquem) } \\
42 \text { Nonionella sp. }\end{array}$ & & & $\begin{array}{l}\text { Cushman, } 1929 ; \mathrm{pl} .13 / 39 \\
\text { Verdenius, } 1970 ; \mathrm{pl} .4 / 12(11,16) \\
\quad- \\
\text { Phleger et al., } 1953 ; \text { pl. } 6 / 3 \\
\text { Verdenius, } 1970 ; \mathrm{pl} .6 / 2 \\
\quad-\end{array}$ \\
\hline
\end{tabular}

Note: The species are arranged in two groups: dominant species. They are arranged according to their number of records among the first three ranked species; additional species. These species are less dominant, but might be of stratigraphical or ecological value. The species numbers given in this list are used in Figure 2. - For taxonomical purposes, references of good figures or descriptions are given: the first number refers to the publication listed under "reference," it is followed by plate and figure number.

2 and 3 represent the upper part of the early Miocene (approximately 14 m.y.B.P.).

Unit 4 is characterized by Pyrgo murrhina and Bolivina multicostata. Displaced shallow water forms were not observed. High frequencies of $R$. multicostata opima are typical (Figure 8). This unit represents the middle Miocene.

Unit 5 shows Uvigerinas which become increasingly dominant. The base of this unit coincides with a major hiatus during most of the late Miocene (Zones N16, N17). This unit roughly corresponds with the lower part of the G. margaritae Zone ( \pm 5 m.y.B.P.).
Unit 6 is defined by the disappearance of $R$. multicostata opima, B. multicostata, and Bulimina alazenensis. It represents the upper part of the $G$. margaritae Zone ( \pm 3-4 m.y.B.P.).

Unit 7 represents the Pleistocene and is characterized by Höglundina elegans.

A rather wide species concept had to be applied in this report. The use of "stage restricted" species names (i.e., Bolivina spatulatha Williamson in the Quaternary, to be replaced by the name $B$. dilatata Reuss from the Vienna Basin when approaching the Miocene) would have created a number of artificial zonal markers with 


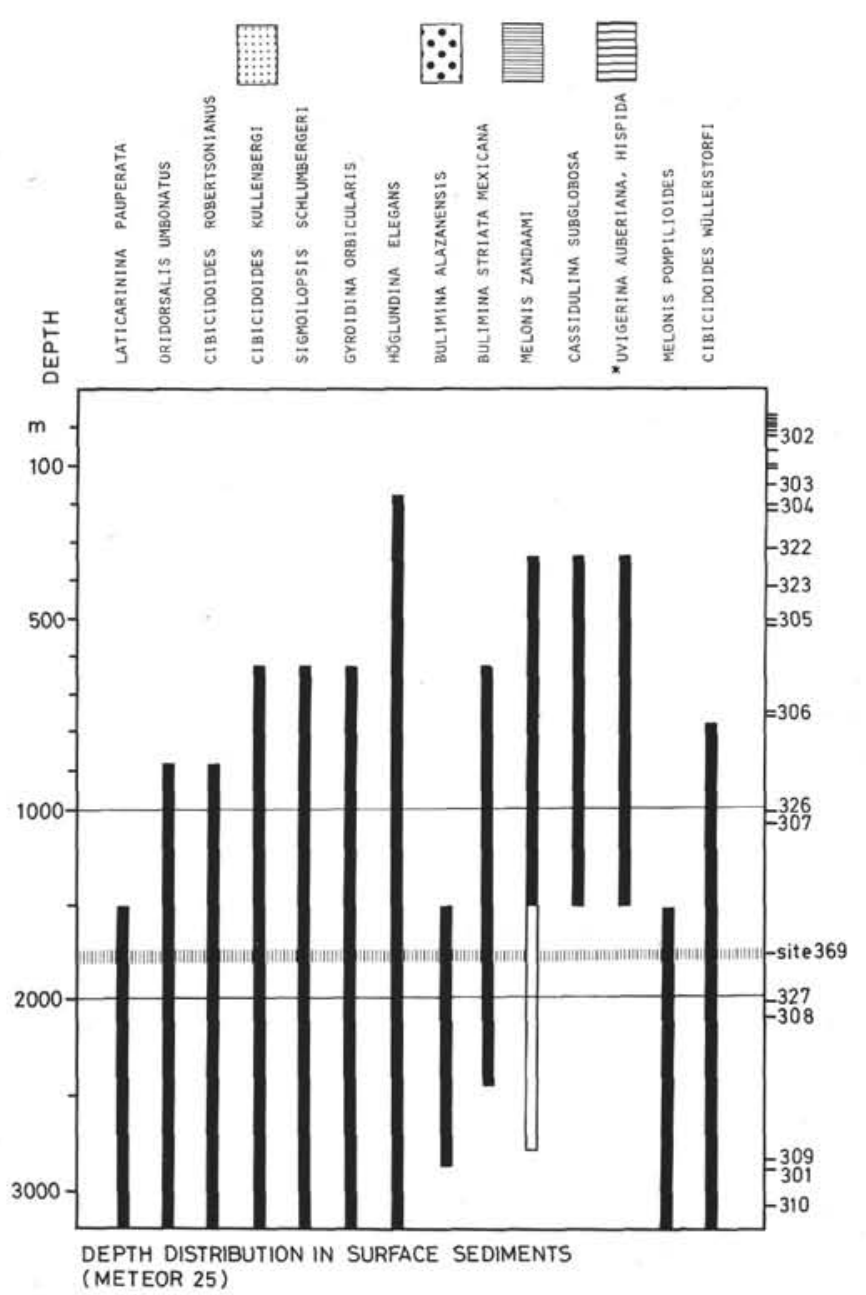

Figure 6. Recent depth distribution of benthonic Foraminifera in surface sediments off Cape Bojador and adjacent areas, based on material from the Meteor 25-expedition. Generalized; living and death population combined. Uvigerina hispida and $\mathrm{U}$. auberiana are mainly based on empty test distribution so their ranges are possibly influenced by reworked Neogene fossil material. The white bar for Melonis zaandami shows the extended distribution of this species farther south.

no real stratigraphic significance. This would simply reflect age determinations based on other microfossil groups. On the other hand, there are obvious alterations in some of the long-ranging species groups (for instance, Cibicidoides kullenbergi s.1.) which might be potentially useful for biostratigraphy.

These problems have been given too little attention, as pointed out by Ingle (1973), and more detailed studies, including biometric analyses, are called for to increase the biostratigraphical usefulness of these foraminifers.

\section{ACKNOWLEDGMENTS}

Thanks are due to the shipboard party of Leg 41 for sampling and helpful discussions. The work was supported by the "Deutsche Forschungsgemeinschaft," Bonn, West Germany. U. Pflaumann provided unpublished data from his contributions to this report.

\section{REFERENCES}

Bandy, O.L. and Chierici, M.A., 1966. Depth-temperature evaluation of selected California and Mediterranean bathyal Foraminifera: Marine Geol., v. 4, p. 259-271.

Cushman, J.A., 1929. A late Tertiary fauna of Venezuela and other related regions: Contrib. Cushm. Lab. Foram. Res., v. 5 , p. $77-101$.

1943. Some new Foraminifera from the Tertiary of the Island of St. Croix: Contrib. Cushm. Lab. Foram. Res., v. 19, p. 91.

Douglas, R.G., 1973. Benthonic foraminiferal biostratigraphy in the Central North Pacific, Leg 17, DSDP. In Winterer, E.L., Ewing, J.L., et al., Initial Reports of the Deep Sea Drilling Project, Volume 17: Washington (U.S. Government Printing Office), p. 607671.

\section{Scotia.}

1975. First Benthonic Symposium: Halifax, Nova

Ingle, J.C., Jr., 1973. Neogene foraminifera from the northeastern Pacific Ocean, Leg 18, Deep Sea Drilling Project. In Kulm, L.D., von Huene, R., et al., Initial Reports of the Deep Sea Drilling Project, Volume 18: Washington (U.S. Government Printing Office), p. 517567.

Loeblich, A.R., Jr. and Tappan, H., 1964. Foraminiferida: Treatise on Invertebrate Paleontology, part C, Protista 2.

Lutze, G.F., 1965. Zur Foraminiferen-Fauna der Ostsee: Meyniana, Kiel, v. 15, p. 75-142.

Parker, F.L., 1958. Eastern Mediterranean Foraminifera: Rept. Swedish Deep-Sea Exped., v. 8, p. 217-283.

1964. Foraminifera from the experimental Mohole drilling near Guadalupe Island, Mexico: J. Paleontol., v. 38, p. $617-637$.

Pflaumann, U., 1975. Late Quaternary stratigraphy based on planktonic foraminifera off Senegal. "Meteor" Forsch.Ergebn. C, v. 23, p. 1-46.

Phleger, F.B., Parker, F.L., and Peirson, J.F., 1953. North Atlantic Foraminifera: Rept. Swedish Deep-Sea Exped., v. 7 , p. $1-122$.

Schnitker, D., 1974. West Atlantic abyssal circulation during the past 120,000 years: Nature, v. 248, p. 385-387.

Verdenius, J.G., 1970. Neogene stratigraphy of the Western Guadalquivir Basin: Utrecht Micropaleontol. Bull., v. 3, p. $1-109$. 
LEG 41

SITE 369
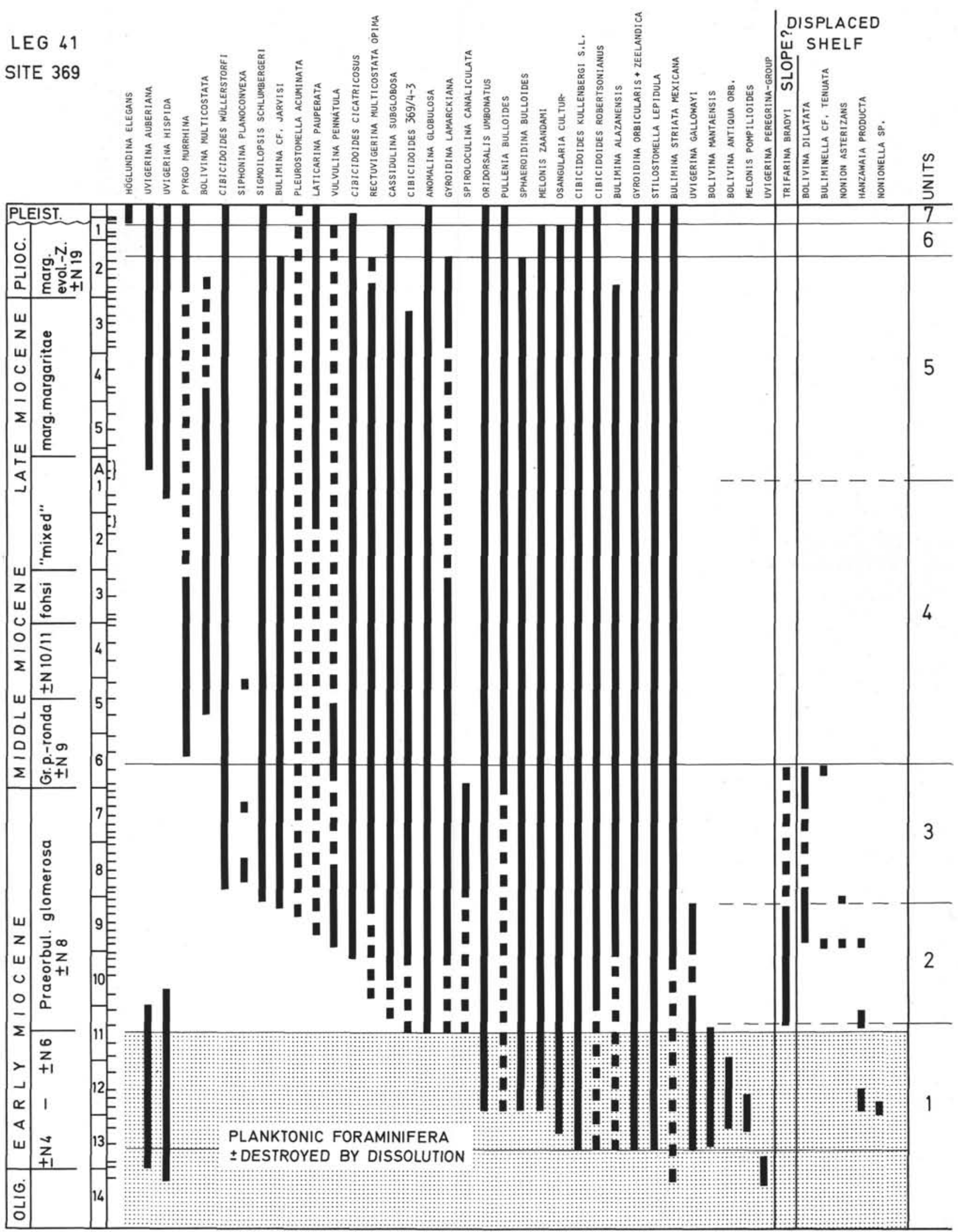

Figure 7. Ranges of dominant Neogene species larger than $250 \mu \mathrm{m}$. In addition, selected species of the finer fractions include Bolivina multicostata, Bulimina alazanensis, Osangularia cultur, and most of the displaced species such as Bolivina dilatata, B. antiqua, and Nonion asterizans. Note the occurrence of displaced shelf species in the upper part of the early Miocene section and the restriction of the lower bathyal Melonis pompilioides to the carbonate dissolution interval at the base of Miocene. 


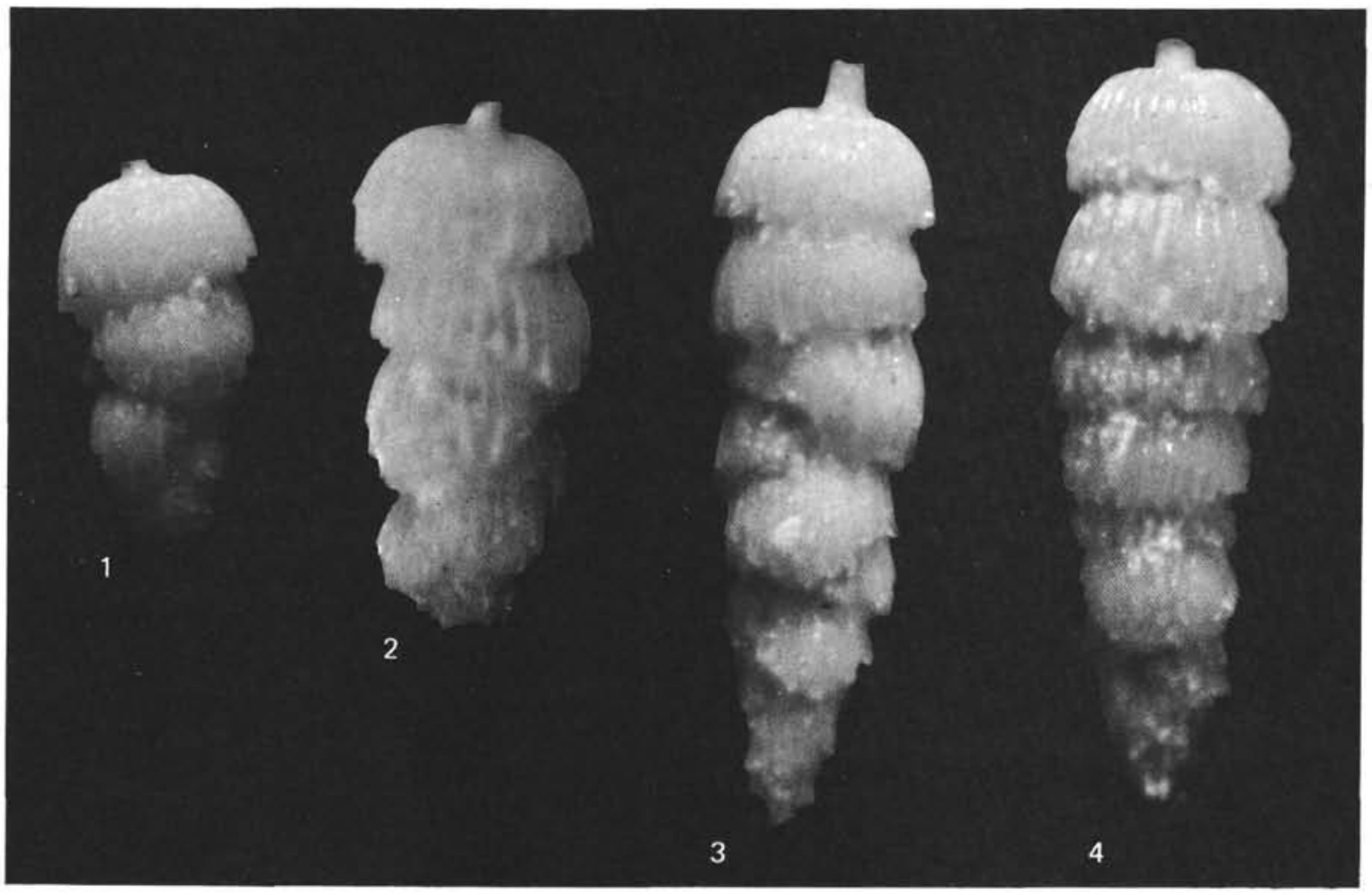

Figure 8. Rectuvigerina multicostata opima (Cushman, 1943). 8(1) thru 8(3) are from: Cores 369A-1 thru 6: sizes $0.52 \mathrm{~mm}, 0.75 \mathrm{~mm}$ and $1.05 \mathrm{~mm} ; 8(4)$ is from Core $369 \mathrm{~A}-4-1: 1.22 \mathrm{~mm}$. 